\title{
Insects Visiting Drippy Blight Diseased Red Oak Trees Are Contaminated with the Pathogenic Bacterium Lonsdalea quercina
}

\author{
Rachael A. Sitz, ${ }^{1, \dagger}$ Vincent M. Aquino, ${ }^{2}$ Ned A. Tisserat, ${ }^{1}$ Whitney S. Cranshaw, ${ }^{1}$ and Jane E. Stewart ${ }^{1}$ \\ ${ }^{1}$ Department of Bioagricultural Sciences and Pest Management, Colorado State University, Fort Collins, CO 80523-1177 \\ ${ }^{2}$ Facilities Management, University of Colorado - Boulder, Boulder, CO 80309
}

\begin{abstract}
The focus of investigation in this study was to consider the potential of arthropods in the dissemination of the bacterium involved in drippy blight disease, Lonsdalea quercina. Arthropod specimens were collected and tested for the presence of the bacterium with molecular markers. The bacterium $L$. quercina was confirmed on 12 different insect samples from three orders (Coleoptera, Hemiptera, and Hymenoptera) and eight families (Buprestidae, Coccinellidae, Dermestidae, Coreidae, Pentatomidae and/or Miridae, Apidae, Formicidae, and Vespidae). Approximately half of the in-

carry it between trees, is conservative because the documented insects represent only a subset of the insect orders that were observed feeding on the bacterium or present on diseased trees yet were not able to be tested. The insects contaminated with L. quercina exhibited diverse life histories, where some had a facultative relationship with the bacterium and others sought it out as a food source. These findings demonstrate that a diverse set of insects naturally occur on diseased trees and may disseminate $L$. quercina.
\end{abstract} sects found to carry the bacterium were in the order Hymenoptera. Estimates of the insects that are contaminated with the bacterium, and likely

Keywords: drippy blight disease, insect dissemination, bacterial detection

Facultative bacterial-insect associations afflicting plants are largely understudied (Calamassi et al. 2008; Chagas et al. 2001; Harris and Maramorosch 1980; Nadarasah and Stavrinides 2011) yet remain critical to understanding many widespread and economically damaging tree diseases (e.g., crown gall, fire blight, citrus canker) (Mansfield et al. 2012). In facultative bacterial relationships, insects may assist bacteria in two main ways: insects can become externally contaminated and transfer phytopathogenic bacteria to new hosts (Thomson et al. 1992; Vanneste 2000), or they can create environments, such as feeding wounds, which act as entry courts and in some cases optimal microclimates for bacterial pathogens (Belasque et al. 2005; Calamassi et al. 2008; Chagas et al. 2001; Granovsky 1940; Hansen and Smith 1937).

In the emergent disease drippy blight, a kermes scale insect, Allokermes galliformis (Riley), produces feeding wounds that are regularly colonized by the bacterium Lonsdalea quercina (syn. Erwinia quercina, Brenneria quercina, and Lonsdalea quercina subsp. quercina Biosca et al. 2003; Brady et al. 2012; Hauben et al. 1998; Hildebrand and Schroth 1967; Li et al. 2017; Poza-Carrión et al. 2008), ultimately causing dieback and death to planted red oaks (Caballero et al. 2014; Sitz et al. 2018; Snelling et al. 2011). The bacterial ooze occurs most readily during summer months, peaking in July. Heavy rainstorms have been observed to wash away the ooze so that it is not visible on blighted branches, but the presence of kermes scale insects as well as disease symptoms such as fallen branches and blighted leaves are still present

${ }^{\dagger}$ Corresponding author: R. Sitz; rachael.sitz@usda.gov

Funding: This research was supported by Colorado State University Agricultural Experiment Station Extension Project 618A and the Tree Research and Education Endowment (TREE) Fund grant 15-JD-01 and the US Forest Service Rocky Mountain Research Station.

Current address of R. A. Sitz: Rocky Mountain Research Station, United States Department of Agriculture Forest Service, Moscow, ID 83843

The author(s) declare no conflict of interest.

Accepted for publication 26 February 2019.

This article is in the public domain and not copyrightable. It may be freely reprinted with customary crediting of the source. The American Phytopathological Society, 2019.
(R. Sitz, personal communication). While the ooze is known to contain viable $L$. quercina exudates (Sitz et al. 2018), the polysaccharide sugar composition and linkages are unknown.

The scale insect associated with drippy blight, A. galliformis, is sessile for much of its life (Bullington and Kosztarab 1985; Gill 1993; Kosztarab 1996; Sitz and Cranshaw 2018), and therefore not well adapted for long-distance dispersal of the bacterium. On the other hand, exudates containing L. quercina emerge from kermes feeding sites and cover surfaces on and surrounding infected trees (Sitz et al. 2018), and red oaks typically host a diverse suite of insects (Fralish 2004). Therefore, documenting whether the suite of insects present on diseased oak trees can become contaminated with the bacterium is particularly important within the drippy blight system, and this is the first step toward understanding their potential role in bacterial dissemination.

Insect presence has long been noted in diseases caused by tree pathogens related to the bacterial species $L$. quercina, including genera such as Brenneria (Denman et al. 2014, 2016) and Erwinia (Dalmacio et al. 2007; Thind and Singh 1976; van der Zwet and Keil 1979). Indeed, over 77 insect genera have been contaminated after visiting the ooze of the bacterial causal agent of fire blight, Erwinia amylovora (van der Zwet and Keil 1979), which suggests a similar trend may be present in the genus Lonsdalea. Several species within the bacterial genus Lonsdalea have been documented near wounds caused by mobile insects that are suspected to move the pathogen (Biosca et al. 2003; Denman et al. 2012, 2014; Izquierdo and Pulido 2013; Li et al. 2014; Lu and Gross 2010; Myhre 1988), including L. quercina (Hildebrand and Schroth 1967; Sitz et al. 2018; Swiecki and Bernhardt 2006). Thus, in order to move forward with management efforts to maintain benefits of urban forests, prevent expensive tree removals, and avoid range expansions of $L$. quercina, it is important to study it in relation to insect presence.

Considering whether insects play a role in the spread of $L$. quercina remains unknown, but it is key to understanding how this bacterium persists and spreads. Therefore, the primary objective of this study was to determine whether arthropods associated with drippy blight-infected oaks become contaminated with $L$. quercina under field conditions. We collected arthropods from a localized area of Colorado known to have drippy blight infections and determined if they were contaminated with the bacterium or were observed feeding on the bacterial exudates. 


\section{Materials and Methods}

Study site and experimental design. This study was conducted from May through mid-October in 2015 and 2016 on four individual drippy blight-infected oaks, two of Quercus rubra L. and Q. palustris Muenchh. at the University of Colorado main campus in Boulder (2015 Q. rubra: $40^{\circ} 01^{\prime} 02.4^{\prime \prime} \mathrm{N}, 105^{\circ} 27^{\prime} 04.9^{\prime \prime} \mathrm{W} ; 2015$ Q. palustris: $40^{\circ} 00^{\prime} 37.0^{\prime \prime} \mathrm{N}, 105^{\circ} 26^{\prime} 72.8^{\prime \prime} \mathrm{W} ; 2016$ Q. rubra: $40^{\circ} 00^{\prime} 44.9^{\prime \prime} \mathrm{N}$, $105^{\circ} 26^{\prime} 93.6^{\prime \prime} \mathrm{W}$, and upon removal of this tree, the trap was moved one block north to $40^{\circ} 00^{\prime} 48.7^{\prime \prime} \mathrm{N}, 105^{\circ} 27^{\prime} 01.8^{\prime \prime} \mathrm{W} ; 2016$ Q. palustris: $\left.40^{\circ} 00^{\prime} 38.1^{\prime \prime} \mathrm{N}, 105^{\circ} 26^{\prime} 32.9^{\prime \prime} \mathrm{W}\right)$. During the course of the experiment, the $Q$. rubra experienced kermes scale and bacterial infections on more than half of the branches; whereas $Q$. palustris infections occurred on less than one-fourth of the branches. Trees ranged from 23 to $43 \mathrm{~cm}$ at breast height, were between 5 and $12 \mathrm{~m}$ tall, and approximately 30 to 60 years old.

Insect specimens collected for testing were identified to order, and further if possible, whereas other arthropods were identified to class. Two methods to detect the bacterium on arthropod samples were used, including testing for the bacterium with DNA extractions and plating techniques with subsequent colony PCR. Both techniques were used because DNA extractions can be limited due to the difficulty of penetrating hardened insect exoskeletons or encountering inhibitors (Hildebrand et al. 2000; Rubin et al. 2014); whereas for colony PCR, plating organisms on media can be time sensitive as faster colonies can overtake slow-growing bacteria.

To collect samples for DNA extractions, nonbaited eight-unit multiple funnel traps (Contech Enterprises Inc., Victoria, British Columbia, Canada) were placed at a height of $3 \mathrm{~m}$ in diseased oak trees and checked in 2-week intervals throughout the field season (eight collections each year, June through September). Specimens in the collection cups were dry at each collection date, but if rain had occurred, a screen $(1.5 \mathrm{~cm}$ diameter) allowed water to drain out of the cups. Cups were removed from trees, and specimens were transferred to individual tubes with sterile forceps and stored at $4^{\circ} \mathrm{C}$ for up to 4 days after the collection date. Collection cups were sterilized at each collection date. Classifications were performed using a dissecting stereomicroscope at $20 \times$ magnification, and then samples were stored at $-20^{\circ} \mathrm{C}$ until they were processed using DNA extraction techniques. The majority of insects were identified to the family level or further if possible, but flies were classified to suborder (Table 1). Noninsect arthropods were identified to subclass and order.

Prior to the experiment, adult female kermes scales visibly contaminated with exudates were plated out to confirm bacterial presence and used to determine optimal methods for DNA extractions. To investigate whether lateral transfer of the bacterium L. quercina occurs with this scale insect, males were collected as pupae, reared into adults, and then tested for the bacterium. Pupae were reared into adults in petri dishes at room temperature, and then two individual adult males and two samples with approximately 30 pooled individuals were tested for the bacterium using DNA extraction techniques.

To collect specimens for plating and subsequent colony PCR identification, any live arthropods seen on diseased oak trees were captured in individual 50-ml sterile collection tubes. Collections occurred once each year (9 August 2015 and 18 July 2016). Upon return to the laboratory, bacterial cultures were grown on nutrient agar in 100-mm-diameter $\times 15$-mm-deep Petri dishes. Forceps were used to streak intact insects onto media, and each side of the insect was pressed into the agar. Plates were incubated at $25^{\circ} \mathrm{C}$ for 3 to 5 days. To determine if L. quercina was externally contaminating the insects, all of the isolated mass-colonies of cream-colored bacteria were tested using colony PCR techniques described below.

Detection of $L$. quercina on arthropod specimens. DNA extractions. Individual specimens (ca. 237) were collected from funnel traps on drippy blight infected oaks and tested using DNAextraction techniques (Table 1) to establish whether the arthropods collected from funnel traps were carrying $L$. quercina either internally or externally. In some cases, the optimal sample weight (approximately $25 \mathrm{mg}$ tissue, as recommended to purify total DNA from animal tissues) was obtained by pooling related insects. Of the arthropods collected in traps, 142 individuals were pooled into
61 samples, and 55 arthropods were tested individually (Table 1). Pooled samples were grouped by genus when possible, but most often insects were pooled by family. On five instances, pooled samples occurred at the order level due to the limitation in number of specimens obtained at the sampling date (Table 1).

DNA was extracted using a DNeasy Blood and Tissue kit (Qiagen, Valencia, CA) following the manufacturer's protocol. First, to homogenize the samples, two steel beads ( $2.3 \mathrm{~mm}$ diameter, BioSpec, Bartlesville, OK) were added to a 2-ml screw cap microcentrifuge tube containing the arthropod sample, lysis buffer, and proteinase $\mathrm{K}$. Tubes were shaken two times for $25 \mathrm{~s}$ at $4.0 \mathrm{~m} / \mathrm{s}$ in a FastPrep FP120 homogenizer (Thermo Savant, CA), then all other steps in the DNA extraction protocol were carried out. The quantity and purity of the DNA obtained from extractions was estimated using a spectrophotometer (Thermo Scientific NanoDrop 1000, Loughborough, UK).

PCR tests. For PCR, reaction mixtures contained $20 \mathrm{ng}$ of template DNA (or no DNA template for negative control), $2 \mu 110 \times$ Standard Taq Reaction Buffer (New England BioLabs Inc., Ipswich, MA), $0.4 \mu 110 \mathrm{mM}$ dNTPs (Roche Applied Science, Indianapolis, IN), $1 \mu \mathrm{l}$ each of $10 \mu \mathrm{M}$ primer, and $0.2 \mu \mathrm{l} \mathrm{Taq}$ DNA Polymerase (New England BioLabs Inc., Ipswich, MA) (total $20 \mu \mathrm{l}$ ). Two primers developed by Shang et al. (2014) to target the flagellar transcriptional regulator (flhD) and DNA gyrase subunit B (gryB) were used to amplify $L$. quercina (flhD forward: 5'-ATGTTGAAACATAGCCTGTTG-3', flhD reverse: $5^{\prime}$-TTATGCCCTTTTCTTAGGCAC-3', and gryB forward: 5'-CTGTACAAGGTGAAGAAAGG-3', gryB reverse: 5'CGTCACCAGCATCTCCATCC-3'). Amplifications were performed using the following PCR conditions: $94^{\circ} \mathrm{C}$ for $3 \mathrm{~min}, 30$ cycles at $94^{\circ} \mathrm{C}$ for $30 \mathrm{~s}, 60^{\circ} \mathrm{C}$ for $30 \mathrm{~s}$, and $72^{\circ} \mathrm{C}$ for $1 \mathrm{~min}$, then finally $72^{\circ} \mathrm{C}$ for $7 \mathrm{~min}$. All PCR reactions were conducted using a MJ PTC-200 thermocycler (Bio-Rad Laboratories, Waltham, MA).

Amplified DNA was confirmed with a Sub-Cell GT Wide Mini electrophoresis system (BioRad, Hercules, CA) that yielded a single band ( $382 \mathrm{~kb}$ in length for flhD or $286 \mathrm{~kb}$ in length for gryB). PCR products were cleaned using a High Pure PCR Product Purification Kit (Roche Life Science, Indianapolis, IN) and sequenced at Genewiz (South Plainfield, NJ). Chromatograms were visualized; sequences were joined to make a consensus and edited manually using Geneious (Kearse et al. 2012). To confirm pathogen presence, $L$. quercina primers and quality nucleotide sequences were first compared against the entire NCBI nonredundant database, and then to the NCBI whole genome shotgun database using the genus Lonsdalea as the organism (taxid: 1082702) (Altschul et al. 1990). The bacterium was confirmed on query that resulted in L. quercina as the most similar hit. Sequences with high quality base calls for all nucleotides were deposited in NCBI Nucleotide Database under the accession numbers MH142829 through MH142832.

Colony PCRs. Plating and subsequent colony PCR methods were performed on 22 individual samples in order to test for the bacterium (Table 1). For colony PCR, bacterial colonies were lysed in $20 \mu \mathrm{l}$ sterile water at $95^{\circ} \mathrm{C}$ for $5 \mathrm{~min}$ and then used in PCR, electrophoresis, sequencing, and identification as described in the PCR testing.

Observation of insects feeding on $\boldsymbol{L}$. quercina. To determine if insects feeding on L. quercina may be indicative of those that become contaminated, diseased trees were surveyed for insect activity. All insects observed feeding on exudates from seven drippy blight diseased trees in Boulder, $\mathrm{CO}$ (the four study trees and three trees located at $\left.40^{\circ} 01^{\prime} 72.89^{\prime \prime} \mathrm{N}, 105^{\circ} 25^{\prime} 99.04^{\prime \prime} \mathrm{W}\right)$ were recorded once each week June to September (13 observations per year). The trees were visited for a half hour each between 8 A.M. and 4 P.M., but on one occasion, observations of only the four study trees occurred between 8 P.M. and 10 P.M. Insects were identified to the family level in the field, and further when possible. All sightings of insects feeding on the bacterium were recorded, and photographs of insects were taken when possible.

\section{Results}

Detection of $L$. quercina on arthropod specimens. Females of $A$. galliformis were found to contain the bacterium. However, neither 
the two samples of individual males, nor the two pooled samples of males tested positive for the bacterium. Over the course of the experiment, samples representing three arthropod classes, six insect orders, and 28 insect families were tested for the bacterium. Of them, $L$. quercina was detected 12 times on insects from three orders (Coleoptera, Hemiptera, Hymenoptera) (Tables 1 and 2). The bacterial DNA sequences obtained from DNA extractions and colony PCRs were comparable in length (97 to 100\% coverage) and similarity (95 to $99 \%$ ) to L. quercina, although one sample with poorer quality reads shared $90 \%$ similarity.

Of the arthropods tested using DNA extraction techniques, $L$. quercina was confirmed on five pooled samples and one individual specimen (Table 2), where approximately $5 \%$ of all samples processed using DNA extraction techniques carried the bacterium each

Table 1. Insects and other arthropods collected on drippy blight diseased oaks located in Boulder, $\mathrm{CO}$ were tested for contamination with the bacterial pathogen Lonsdalea quercina using DNA extraction or colony PCR techniques. Insect specimens were classified to order and family when possible. If insects from two families were pooled for DNA extractions, both families are listed. The number of pooled samples is followed by the number of individuals tested in the pools for each family. If two families were tested, numbers are listed respectively and separated by commas. Footnotes indicate any alternative classifications used. The number of individuals tested for the bacterium is listed for each family, and the percent and number that tested positive for the bacterium using DNA extraction or colony PCR methods are presented for each order.

\begin{tabular}{|c|c|c|c|c|c|}
\hline $\begin{array}{l}\text { Classification } \\
\text { Subdivision }\end{array}$ & $\begin{array}{l}\text { Number pooled samples } \\
\text { tested (number individuals } \\
\text { pooled) using DNA } \\
\text { extractions }\end{array}$ & $\begin{array}{l}\text { Number individual } \\
\text { specimens tested } \\
\text { using DNA extractions }\end{array}$ & $\begin{array}{l}\text { Percent (number) infected } \\
\text { samples using DNA } \\
\text { extractions }\end{array}$ & $\begin{array}{l}\text { Number individuals } \\
\text { tested using } \\
\text { colony PCR }\end{array}$ & $\begin{array}{c}\text { Percent (number) } \\
\text { infected samples } \\
\text { using colony PCR }\end{array}$ \\
\hline Hymenoptera & & & $14 \%(4)$ & & $30 \%(3)$ \\
\hline Apidae & & 1 & & 5 & \\
\hline Vespidae & $1(2)$ & 11 & & 5 & \\
\hline Formicidae & $11(31)$ & 2 & & & \\
\hline Unknown & $2(7)$ & & & & \\
\hline Hemiptera & & & $3 \%(1)$ & & $100 \%(1)$ \\
\hline Membracidae & $6(17)$ & 8 & & & \\
\hline $\begin{array}{l}\text { Membracidae and } \\
\text { Cicadellidae }\end{array}$ & $1(1,1)$ & & & & \\
\hline $\begin{array}{l}\text { Membracidae and } \\
\text { Miridae }\end{array}$ & $1(1,1)$ & & & & \\
\hline Cicadellidae & $2(4)$ & 2 & & & \\
\hline Aphididae & $3(8)$ & & & & \\
\hline Psyllidae & & 1 & & & \\
\hline Reduviidae & & 1 & & & \\
\hline Coreidae & & 1 & & 1 & \\
\hline Pentatomidae & & 2 & & & \\
\hline $\begin{array}{l}\text { Pentatomidae and } \\
\text { Miridae }\end{array}$ & $1(1,1)$ & & & & \\
\hline Miridae & $3(6)$ & 1 & & & \\
\hline Coleoptera & & & $3 \%(1)$ & & $22 \%(2)$ \\
\hline Dermestidae & $9(35)$ & 2 & & 2 & \\
\hline $\begin{array}{c}\text { Dermestidae and } \\
\text { Staphylinidae }\end{array}$ & $1(2,1)$ & & & & \\
\hline Buprestidae & & & & 1 & \\
\hline Coccinellidae & & 8 & & 5 & \\
\hline Latridiidae & $1(5)$ & & & & \\
\hline Curculionidae & $2(8)$ & & & & \\
\hline Carabidae & $2(6)$ & 1 & & & \\
\hline Nitidulidae & & 1 & & & \\
\hline $\begin{array}{l}\text { Histeridae and } \\
\text { Lampyridae }\end{array}$ & $1(1,1)$ & & & & \\
\hline Scarabaeidae & & 2 & & & \\
\hline Staphylinidae & $2(6)$ & & & 1 & \\
\hline Unknown & & & & 1 & \\
\hline Diptera & & & $0 \%(0)$ & & $0 \%(0)$ \\
\hline Brachycera $^{a}$ & $4(18)$ & & & 1 & \\
\hline Nematocera $^{a}$ & $4(10)$ & 2 & & 1 & \\
\hline Dermaptera & & & $0 \%(0)$ & & $0 \%(0)$ \\
\hline Forficulidae & $1(2)$ & 3 & & & \\
\hline Neuroptera & & & $0 \%(0)$ & & $0 \%(0)$ \\
\hline Rhaphidioptera ${ }^{\mathrm{a}}$ & & 1 & & & \\
\hline Chrysopidae & & 1 & & & \\
\hline Arachnida $^{\mathrm{b}}$ & & & $0 \%(0)$ & & $0 \%(0)$ \\
\hline Acaric & $2(4)$ & 1 & & & \\
\hline Aranae $^{\mathrm{d}}$ & $1(2)$ & 1 & & & \\
\hline Opiliones $^{\mathrm{d}}$ & & 1 & & & \\
\hline Diplopoda $^{\mathrm{b}}$ & & & $0 \%(0)$ & & $0 \%(0)$ \\
\hline Unknown & & 1 & & & \\
\hline
\end{tabular}

${ }^{a}$ Classified into suborder rather than family.

${ }^{\mathrm{b}}$ Classified into class rather than order.

${ }^{c}$ Classified into subclass rather than family.

${ }^{\mathrm{d}}$ Classified into order rather than family. 
year (Table 1). Samples from the six bacterial confirmations were collected from five of the 16 collection points; three of the pooled samples carrying the bacterium were collected in July, two in August, and one individual specimen in September. Cross-contamination of samples collected from the funnel traps was unlikely, as insects seldom carried L. quercina and were spread across multiple collection dates. Six out of the 22 individual insects tested using colony-PCR tested positive for the bacterium (Table 1). In both sampling years, approximately $25 \%$ of the insects collected for colony PCR tested positive for the bacterium (Table 1).

Overall, eight insect families were found positive for contamination with L. quercina (Buprestidae, Coccinellidae, Dermestidae, Coreidae, Pentatomidae and/or Miridae, Apidae, Formicidae, and Vespidae). Two individual coleopteran specimens tested positive for the bacterium and were recognized to the species level, including a buprestid, the flatheaded appletree borer, Chrysobothris femorata Olivier, and a coccinellid, the multicolored Asian lady beetle, Harmonia axyridis (Pallas) (Fig. 1E). The remaining coleopteran sample that tested positive was a pooled sample containing five Dermestid

Table 2. Pooled samples of insects collected on drippy blight diseased oaks located in Boulder, $\mathrm{CO}$ with confirmed Lonsdalea quercina presence using DNA extraction techniques. Insect specimens are organized by order and classified to family. The number of individuals in the pooled sample is indicated, if multiple families were tested in a single pool, the number of individuals in each family are listed respectively and separated by commas.

\begin{tabular}{lc}
\hline Insect classification & $\begin{array}{c}\text { No. individuals in positive } \\
\text { pooled samples }\end{array}$ \\
\hline Hymenoptera & \\
Formicidae & 4 \\
Formicidae & 2 \\
Formicidae & 5 \\
Hemiptera & 2 \\
Pentatomidae and Miridae & 1,1 \\
Coleoptera & \\
Dermestidae & 5 \\
\hline
\end{tabular}

beetles in the genus Trogoderma (Fig. 1B; NCBI accession number MH142832). The bacterium was confirmed on an individual western conifer-seed bug Leptoglossus occidentalis Heidemann (Hemiptera: Coreidae) specimen, and one pooled sample containing a stink bug and a plant bug (Hemiptera: Pentatomidae and Miridae, respectively) also tested positive for the bacterium.

Insects in the order Hymenoptera were most frequently documented to carry L. quercina; this group included three of the five positive pooled samples, four of the seven positive specimens (Tables 1 and 2), and represented three of the eight insect families that carried the pathogen. In addition, Hymenoptera was the only order to have multiple individual specimens as well as pooled samples in the same family test positive for L. quercina (Tables 1 and 2). Specimens included two individual honey bees (Apis mellifera L., Fig. 1D; NCBI accession number MH142829) and two individual western yellowjackets (Vespula pensylvanica Saussure; NCBI accession number MH142830) that tested positive for L. quercina. Additionally, three pooled samples of ants (family Formicidae) had confirmed L. quercina (Table 2; NCBI accession numbers MH142831 and MH142833).

Observation of insects feeding on $L$. quercina. Field observations of insects feeding on the bacterium made during the course of data collection indicated that a variety of insects visit the ooze produced by L. quercina (Table 3 ). Of the nine insect families observed feeding on the bacterium (Table 3), seven insect families were collected in traps or tested via colony PCR to determine $L$. quercina presence, and six of them were confirmed to carry L. quercina (Apidae, Formicidae, Vespidae, Coccinellidae, Dermestidae, and Coreidae). Scatopsid flies (Diptera: Scatopsidae; Fig. 1A) and cutworm moths (Lepidoptera: Noctuidae; Fig. 1F) were observed feeding on the exudates but were not able to be tested. Several kinds of beetles, including additional species (i.e., other than multicolored Asian lady beetle) of lady beetles (Coleoptera: Coccinellidae; Fig. 1C) and bumble flower beetles, Euphoria inda L. (Coleoptera: Scarabeaeidae) were noted feeding on the exudates during the time of collection, but the bacterium was not amplified from the specimens tested for the bacterium. Hymenopteran specimens were the most frequent order observed on diseased trees, including one bumble bee

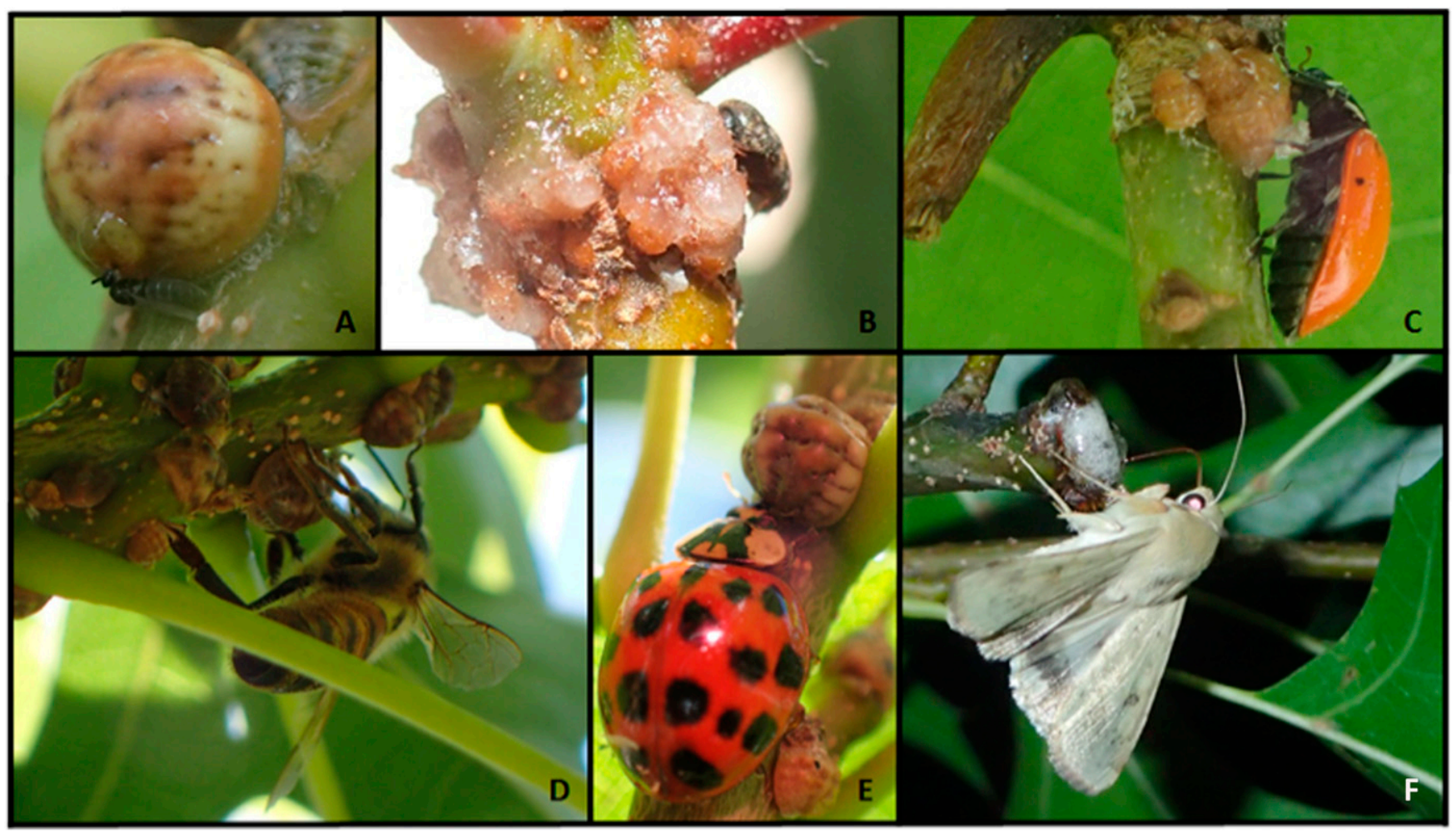

Fig. 1. Images of insects feeding on Lonsdalea quercina: (A) Diptera: Scatopsidae; (B) Coleoptera: Dermestidae; (C and E) Coleoptera: Coccinellidae; (D) Hymenoptera: Apidae; and (F) Lepidoptera: Noctuidae. 
(Hymenoptera: Apidae, Bombus sp.), and vespid wasps including two baldfaced hornets (Dolichovespula maculata L.), four aerial yellowjackets (Dolichovespula arenaria Fabr.), one European paper wasp (Polistes dominula Christ), two paper wasps (Polistes fuscatus aurifer Saussure), and one unidentified yellowjacket (Vespula sp.).

\section{Discussion}

A suite of potential disseminators visited drippy blight diseased trees; the insects sampled were from 6 insect orders and 28 families. Of them, L. quercina was found on 12 specimens from three orders (Coleoptera, Hemiptera, and Hymenoptera) and eight families (Buprestidae, Coccinellidae, Dermestidae, Coreidae, Pentatomidae and/or Miridae, Apidae, Formicidae, and Vespidae). Importantly, insects that tested positive for the bacterium exhibited differing life histories and varied in their host specificity and relationship to the bacterium. Some displayed qualities of more specialized herbivores that used red oak trees as a primary host (e.g., the pin oak kermes Allokermes galliformis and the buprestid wood borer Chrysobothris femorata), and are likely facultative disseminators due to the potential frequent physical contact with the bacterium. In contrast, many more were generalist, cosmopolitan insects; some of which appeared to actively seek out bacterial exudates as a food source (e.g., honey bee Apis mellifera, western yellowjacket Vespula pensylvanica, western conifer seed bug Leptoglossus occidentalis, and multicolored Asian ladybeetle Harmonia axyridis, and insects in the families Pentatomidae and/or Miridae, Dermestidae, and Formicidae). Both specialist herbivores and generalist cosmopolitan insects are likely important in the spread of this pathogen. Due to their generalist nature, cosmopolitan insects likely visit a range of hosts and move between them frequently; whereas specialist insects potentially spread the bacterium within or between a limited number of hosts but may initiate feeding wounds that allow for the entry of the bacterium.

Female pin oak kermes scales (Allokermes galliformis) are regularly contaminated with L. quercina (Sitz et al. 2018), but the more mobile males of this species were not among the insects contaminated with the bacterium. Therefore, it is unlikely that lateral transfer of this bacterium exists with A. galliformis. However, previous work on this disease complex suggests that $A$. galliformis plays several indirect roles in the dissemination of L. quercina associated with drippy blight disease. For example, the first instar kermes scales migrate to new growth where they begin feeding in the spring, and during this process may crawl over dried exudates and overwintering cankers (Sitz and Cranshaw 2018; Sitz et al. 2018). Perhaps more importantly, most of the drippy blight disease exudation to the plant surface is from scale feeding sites (Sitz et al. 2018), allowing the bacteria to become accessed by other insects. Here, we show many insects visit the female scales that are covered with exudates throughout the summer (Fig. 1A-E). We hypothesize that the bacterium benefited by co-occurring with the kermes scale, an indication that

Table 3. The number of insects observed feeding on the bacterial causal agent of drippy blight disease, Lonsdalea quercina, present in diseased oaks located in Boulder, CO. Insects are organized by order and classified family.

\begin{tabular}{lc}
\hline Insect classification & Number of individuals observed \\
\hline Hymenoptera & $>200$ \\
$\quad$ Apidae & 4 \\
$\quad$ Vespidae & 1 \\
$\quad$ Formicidae & \\
Hemiptera & 1 \\
$\quad$ Coreidae & \\
Coleoptera & 2 \\
$\quad$ Scarabaeidae & 7 \\
$\quad$ Coccinellidae & 1 \\
$\quad$ Dermestidae & \\
Diptera & 1 \\
$\quad$ Scatopsidae & \\
Lepidoptera & 3 \\
$\quad$ Noctuidae & \\
\hline
\end{tabular}

they exhibit a commensal bacterial-insect association where L. quercina was able to exude from the kermes scales feeding sites in order to more easily be spread.

Other insects that use red oak as a primary host may also create feeding wounds that could play an indirect role in disease transmission, but are also mobile and could contribute directly to the onset and spread of drippy blight disease. Specifically, adults of the buprestid borer Chrysobothris femorata, which develops as a wood borer within red oak, was found contaminated with L. quercina. This finding supports a previously documented association between wood borers in the family Buprestidae and bacterial tree diseases. For example, diffuse cankers occur when galleries of the two spotted oak borer (Agrilus biguttatus Fab.) touch bacterial lesions of acute oak decline (Brown et al. 2014; Denman et al. 2012, 2014). In addition, wood borers are responsible for creating wounds that allow new infections of fire blight in apple and pear orchards (Hildebrand et al. 2000). Overall, several oak-feeding insects were contaminated with L. quercina; however, generalist insects were more abundant on diseased trees and therefore may play an outsized role in dissemination.

Red oaks showing symptoms of drippy blight disease attracted a suite of insects, with social Hymenopterans as the most abundant group of insects visiting and becoming contaminated with the bacterium. In particular, ants were the most frequently recorded insects carrying the bacterium (Table 1; Fig. 1B) and were observed feeding on diseased tree exudates. Interestingly, Allokermes galliformis rely on ants to physically remove their sugar-rich excrements, avoiding honeydew accumulation close to their bodies (Gullan and Kosztarab 1997; Kosztarab 1996; Turner and Buss 2005). This suggests the mutualistic relationship between kermes scale insects and ants may be important in drippy blight disease transmission, especially if ants further spread L. quercina while tending to A. galliformis.

Winged hymenopterans moved readily within and between trees and tested positive for the bacterium; therefore, they may be more important than other nonwinged insects in the long-distance spread of the bacterium. The honey bee (Apis mellifera) was the most abundant insect observed visiting drippy blight affected trees, and during midsummer hundreds of bees might be seen feeding on the exudates present on a single tree. Honey bees are known to ingest Lonsdalea and related pathogens (Brady et al. 2012; Budge et al. 2016; Mattila et al. 2012); therefore, it is likely they also ingest L. quercina. We hypothesize that another important group of winged hymenopterans, social wasps, were also attracted to drippy blight diseased trees. Two western yellowjackets (Vespula pensylvanica) were found contaminated with L. quercina, and this is the first time this species has been reported as contaminated with a phytopathogenic bacterium. Eusocial wasps may have been attracted to bacterial-derived products (del Pilar Marquez-Villavicencio et al. 2011; Landolt and Zhang 2016; Landolt et al. 2014) or scale insect volatiles and sugary tree sap (Brown et al. 2015; Martinson et al. 2013). It is likely that eusocial wasps are important disseminators because associations between Vespula sp. and bacterial infections of plants involving the genera Lonsdalea and Erwinia have been reported (Myhre 1988; van der Zwet and Keil 1979). Therefore, future studies that elucidate the link between hymenopteran insects and phytopathogenic bacteria are a clear step forward to understanding the role insects play in the dissemination of drippy blight disease.

Our estimate of the number of potential disseminators is likely conservative as more insect groups feeding on the bacterial exudates or attracted to diseased trees were observed than those that were found contaminated with L. quercina. There were limitations in sampling and detection methods used in this study that may have restricted which insects were collected or which were proven contaminated. For example, multiple funnel traps and live collections during the day limited the collection of insects to day active species, and night visiting species such as noctuid moths were likely undersampled. Samples processed using colony PCR techniques detected a higher percentage of insects carrying the bacterium when compared with DNA extraction techniques. For example, we observed scarab beetles and lady beetles feeding on the bacterium that did not test positive for the pathogen using the DNA extraction method. This 
phenomenon has been documented before (Hildebrand et al. 2000), and may be attributed to the difficulties of extracting bacterial DNA from insect samples (Rubin et al. 2014).

Oak trees support thriving communities of insects, and the insect groups that are involved in dissemination of the L. quercina diseases will likely vary by region. For example, L. quercina has been documented in California in association with seed-feeding weevils, cynipid gall wasps, and filbertworms (Cydia latiferreana Walsingham) (Izquierdo and Pulido 2013; Swiecki and Bernhardt 2006). This suite of insects is not associated with red oaks in Colorado. Therefore, depending on the location and species of oak infected with $L$. quercina, a unique group of insects may become contaminated with the bacterium and play a role in disease progression.

The kermes scale A. galliformis is thought of as the insect causal agent of drippy blight disease. Although this kermes scale is sessile during the summer months, it creates primary sites of bacterial exudation (Sitz et al. 2018), and we observed many opportunistic insects visiting the ooze. This study is the first to document a diverse suite of generalist insects that were directly linked to the drippy blight pathogen L. quercina. These potential disseminators exhibit starkly different lifestyles; and bacterial contamination was documented not only on insects that use red oak as a primary host such as wood borers, but also on generalist pollinators such as honey bees, herbivorous true bugs, predatory lady beetles, and scavengers such as dermestid beetles and yellowjackets, all of which were also observed feeding on the bacterium. Our findings are important, as environments containing trees infected with $L$. quercina pathogens sustain diverse insect communities with species that may aid in disease dissemination.

\section{Acknowledgments}

We thank Boulder City Foresters Kathleen Alexander, Kendra Nash, Pat Bohin, and Tom Read for their help in locating drippy blight diseased trees. Erika Peirce, Kellie Due, and Austin Broberg provided field or laboratory assistance, and Emily Luna, Kristen Otto, and Jorge Ibarra Caballero provided technical assistance. In addition, we are grateful for the comments to improve this manuscript, including revisions by Stacy Endriss, Sarah B. Miller, and anonymous reviewers.

\section{Literature Cited}

Altschul, S. F., Gish, W., Miller, W., Myers, E. W., and Lipman, D. J. 1990. Basic local alignment search tool. J. Mol. Biol. 215:403-410.

Belasque, J., Jr., Parra-Pedrazzoli, A. L., Rodrigues Neto, J., Yamamoto, P. T., Chagas, M. C. M., Parra, J. R. P., Vinyard, B. T., and Hartung, J. S. 2005. Adult citrus leafminers (Phyllocnistis citrella) are not efficient vectors for Xanthomonas axonopodis pv. citri. Plant Dis. 89:590-594.

Biosca, E. G., González, R., López-López, M. J., Soria, S., Montón, C., PérezLaorga, E., and López, M. M. 2003. Isolation and characterization of Brenneria quercina, causal agent for bark canker and drippy nut of Quercus spp. in Spain. Phytopathology 93:485-492.

Brady, C. L., Cleenwerck, I., Denman, S., Venter, S. N., Rodríguez-Palenzuela, P., Coutinho, T., and De Vos, P. 2012. Proposal to reclassify Brenneria quercina (Hildebrand and Schroth 1967) Hauben et al. 1999 into a new genus, Lonsdalea gen. nov., as Lonsdalea quercina comb. nov., descriptions of Lonsdalea quercina subsp. quercina comb. nov., Lonsdalea quercina subsp. iberica subsp. nov. and Lonsdalea quercina subsp. britannica subsp. nov., emendation of the description of the genus Brenneria, reclassification of Dickeya dieffenbachiae as Dickeya dadantii subsp. dieffenbachiae comb. nov., and emendation of the description of Dickeya dadantii. Int. J. Syst. Evol. Microbiol. 62:1592-1602.

Brown, N., Inward, D. J., Jeger, M., and Denman, S. 2014. A review of Agrilus biguttatus in UK forests and its relationship with acute oak decline. Forestry 88:53-63.

Brown, R. L., El-Sayed, A. M., Unelius, C. R., Beggs, J. R., and Suckling, D. M. 2015. Invasive Vespula wasps utilize kairomones to exploit honeydew produced by sooty scale insects. Ultracoelostoma J. Chem. Ecol. 41:1018-1027.

Budge, G. E., Adams, I., Thwaites, R., Pietravalle, S., Drew, G. C., Hurst, G. D., Tomkies, V., Boonham, N., and Brown, M. 2016. Identifying bacterial predictors of honey bee health. J. Invertebr. Pathol. 141:41-44.

Bullington, S., and Kosztarab, M. 1985. Revision of the family Kermesidae (Homoptera) in the Nearctic Region based on adult and third instar females. Virginia Polytechnic Institute and State University 85-11.

Caballero, J. I., Zerillo, M. M., Snelling, J., Cranshaw, W., Boucher, C., and Tisserat, N. 2014. Genome sequences of strain ATCC 29281 and pin and northern red oak isolates of Lonsdalea quercina subsp. quercina. Genome Announc. 2:e00584-e14.

Calamassi, R., Mori, B., Moscatelli, F., Alberghini, S., Battisti, A., Mugnai, L., and Surico, G. 2008. Aleppo pine knot disease: Histology of the knots, detection of causal agent and mode of transmission. Phytopathol. Mediterr. 47:61-72.
Chagas, M., Parra, J. R., Namekata, T., Hartung, J. S., and Yamamoto, P. T. 2001. Phyllocnistis citrella Stainton (Lepidoptera: Gracillariidae) and its relationship with the citrus canker bacterium Xanthomonas axonopodis pv. citri in Brazil. Neotrop. Entomol. 30:55-59.

Dalmacio, S. C., Lugod, T. R., Serrano, E. M., and Munkvold, G. P. 2007. Reduced incidence of bacterial rot on transgenic insect-resistant maize in the Philippines. Plant Dis. 91:346-351.

del Pilar Marquez-Villavicencio, M., Weber, B., Witherell, R. A., Willis, D. K., and Charkowski, A. O. 2011. The 3-hydroxy-2-butanone pathway is required for Pectobacterium carotovorum pathogenesis. PLoS One 6:e22974.

Denman, S., Brady, C., Kirk, S., Cleenwerck, I., Venter, S., Coutinho, T., and De Vos, P. 2012. Brenneria goodwinii sp. nov., associated with acute oak decline in the UK. Int. J. Syst. Evol. Microbiol. 62:2451-2456.

Denman, S., Brown, N., Kirk, S., Jeger, M., and Webber, J. 2014. A description of the symptoms of acute oak decline in Britain and a comparative review on causes of similar disorders on oak in Europe. Forestry 87:535-551.

Denman, S., Plummer, S., Kirk, S., Peace, A., and McDonald, J. E. 2016. Isolation studies reveal a shift in the cultivable microbiome of oak affected with acute oak decline. Syst. Appl. Microbiol. 39:484-490.

Fralish, J. S. 2004. The keystone role of oak and hickory in the central hardwood forest. Pages 78-87 in: Upland Oak Ecology Symposium: History, Current Conditions, and Sustainability. M. A. Spetich, ed. USDA Forest Service Gen. Tech. Rep. SRS-373.

Gill, R. J. 1993. The scale insects of California. Analysis and Identification Branch Division of Plant Industry, California Department of Food and Agriculture.

Granovsky, A. A. 1940. The relation of subterranean insects to the Raspberry crown gall.Hoosier Hort. 22.

Gullan, P. J., and Kosztarab, M. 1997. Adaptations in scale insects. Annu. Rev. Entomol. 42:23-50.

Hansen, H., and Smith, R. 1937. A bacterial gall disease of douglas fir, Pseudotsuga taxifolia. Hilgardia 10:567-577.

Harris, K. F., and Maramorosch, K., eds. 1980. Vectors of plant pathogens. Academic Press, New York, New York.

Hauben, L., Moore, E. R., Vauterin, L., Steenackers, M., Mergaert, J., Verdonck, L., and Swings, J. 1998. Phylogenetic position of phytopathogens within the Enterobacteriaceae. Syst. Appl. Microbiol. 21:384-397.

Hildebrand, D. C., and Schroth, M. N. 1967. A new species of Erwinia causing the drippy nut disease of live oaks. J. Phytopathol. 57:250-253.

Hildebrand, M., Dickler, E., and Geider, K. 2000. Occurrence of Erwinia amylovora on insects in a fire blight orchard. J. Phytopathol. 148:251-256.

Izquierdo, L. P., and Pulido, F. 2013. Spatiotemporal variation in acorn production and damage in a Spanish holm oak (Quercus ilex) dehesa. For. Syst. 22: 106-113.

Kearse, M., Moir, R., Wilson, A., Stones-Havas, S., Cheung, M., Sturrock, S., Buxton, S., Cooper, A., Markowitz, S., Duran, C., Thierer, T., Ashton, B., Meintjes, P., and Drummond, A. 2012. Geneious Basic: An integrated and extendable desktop software platform for the organization and analysis of sequence data. Bioinformatics 28:1647-1649.

Kosztarab, M. 1996:Page 650 in: Scale insects of northeastern North America: Identification, biology, and distribution. Virginia Museum of Natural History, Martinsville, VA.

Landolt, P., and Zhang, Q. H. 2016. Discovery and development of chemical attractants used to trap pestiferous social wasps (Hymenoptera: Vespidae). J. Chem. Ecol. 42:655-665.

Landolt, P. J., Cha, D. H., Werle, C. T., Adamczyk, J. J., Meagher, R. L., Gilbride, R. L., Clepper, T. S., Reed, H. C., Teal, P. E. A., and Sampson, B. J. 2014 Polistes spp. (Hymenoptera: Vespidae) orientation to wine and vinegar. Fla. Entomol. 97:1620-1630.

Li, Y., He, W., Ren, F., Guo, L., Chang, J., Cleenwerck, I., Ma, Y., and Wang, H. 2014. A canker disease of Populus $\times$ euramericana in China caused by Lonsdalea quercina subsp. populi. Plant Dis. 98:368-378.

Li, Y., Xue, H., Guo, L. M., Koltay, A., Palacio-Bielsa, A., Chang, J., Xie, S., and Yang, X. 2017. Elevation of three subspecies of Lonsdalea quercina to species level: Lonsdalea britannica sp. nov., Lonsdalea iberica sp. nov. and Lonsdalea populi sp. nov. Int. J. Syst. Evol. Microbiol. 67:4680-4684.

Lu, S. E., and Gross, D. C. 2010. Drippy pod of white lupine: A new bacteria disease caused by a pathovar of Brenneria quercina. Plant Dis. 94:1431-1440.

Mansfield, J., Genin, S., Magori, S., Citovsky, V., Sriariyanum, M., Ronald, P., Dow, M., Verdier, V., Beer, S. V., Machado, M. A., Toth, I. A. N., Salmond, G., and Foster, G. D. 2012. Top 10 plant pathogenic bacteria in molecular plant pathology. Mol. Plant Pathol. 13:614-629.

Martinson, H. M., Raupp, M. J., and Shrewsbury, P. M. 2013. Invasive stink bug wounds trees, liberates sugars, and facilitates native Hymenoptera. Ann. Entomol. Soc. Am. 106:47-52.

Mattila, H. R., Rios, D., Walker-Sperling, V. E., Roeselers, G., and Newton, I. L. 2012. Characterization of the active microbiotas associated with honey bees reveals healthier and broader communities when colonies are genetically diverse. PLoS One 7:e32962.

Myhre, E. A. 1988. Effects of Lygus spp. (Hemiptera: Miridae) on Mediterranean white lupin (Lupinus albus). M.S. thesis. Washington State University, Pullman, WA.

Nadarasah, G., and Stavrinides, J. 2011. Insects as alternative hosts for phytopathogenic bacteria. FEMS Microbiol. Rev. 35:555-575. 
Poza-Carrión, C., Aguilar, I., Gallego, F. J., Nuñez-Moreno, Y., Biosca, E. G., González, R., López, M. M., and Rodríguez-Palenzuela, P. 2008. Brenneria quercina and Serratia spp. isolated from Spanish oak trees: Molecular characterization and development of PCR primers. Plant Pathol. 57: 308-319.

Rubin, B. E., Sanders, J. G., Hampton-Marcell, J., Owens, S. M., Gilbert, J. A., and Moreau, C. S. 2014. DNA extraction protocols cause differences in 16S rRNA amplicon sequencing efficiency but not in community profile composition or structure. Microbiology Open 3:910-921.

Shang, J., Liu, B. L., and He, W. 2014. A new method to detect Lonsdalea quercina in infected plant tissues by real-time PCR. For. Pathol. 45:28-35.

Sitz, R. A., and Cranshaw, W. S. 2018. Life history of Allokermes galliformis (Hemiptera:Kermesidae) in Colorado. Ann. Entomol. Soc. Am. 111: 265-270.

Sitz, R. A., Zerillo, M. M., Snelling, J., Caballero, J. I., Alexander, K., Nash, K., Tisserat, N. A., Cranshaw, W. S., and Stewart, J. E. 2018. Drippy blight, a disease of red oaks produced from the combined effect of the scale insect, Allokermes galliformis and the bacterium Lonsdalea quercina subsp. quercina. Arboricultur. Urban For. 44:146-153.
Snelling, J., Tisserat, N. A., and Cranshaw, W. 2011. Kermes scale (Allokermes sp.) and the drippy nut pathogen (Brenneria quercina) associated with a decline of red oak species in Colorado. Phytopathology 101:S168.

Swiecki, T. J., and Bernhardt, E. A. 2006. A field guide to insects and diseases of California oaks. Gen. Tech. Rep. PSW-GTR-197. Pacific Southwest Research Station, Forest Service, U.S. Department of Agriculture, Albany, CA.

Thind, B. S., and Singh, N. 1976. Maize borer [Chilo partellus (Swinhoe)] as carrier of Erwinia carotovora var. zeae, the causal agent of bacterial stalk rot of maize. Curr. Sci. 45:117-118.

Thomson, S. V., Hansen, D. R., Flint, K. M., and Vandenberg, J. D. 1992 Dissemination of bacteria antagonistic to Erwinia amylovora by honey bees. Plant Dis. 76:1052-1056.

Turner, J. C. L., and Buss, E. A. 2005. Biology and management of Allokermes kingi (Hemiptera: Kermesidae) on oak trees (Quercus spp.). J. Arboric. 31:198-202.

van der Zwet, T., and Keil, H. L. 1979. Fire blight, a bacterial disease of rosaceous plants. Agriculture Handbook no. 510. U.S. Government Printing Office, Washington, D.C.

Vanneste, J. L., ed. 2000. Fire blight: The disease and its causative agent, Erwinia amylovora. CABI 